"The relationship between derivative instruments and systematic risk: a study on banks trading on BIST"

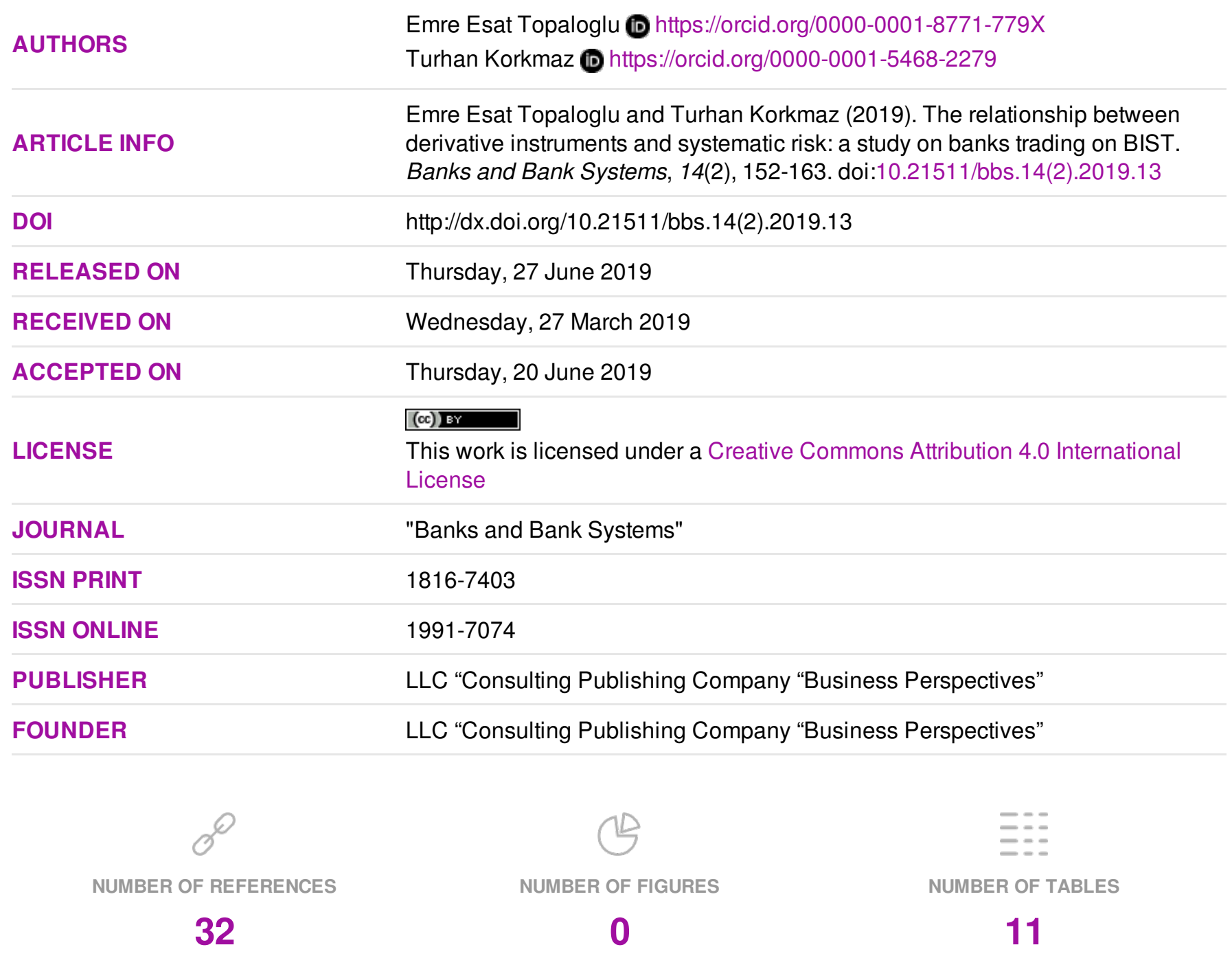

(C) The author(s) 2022. This publication is an open access article. 


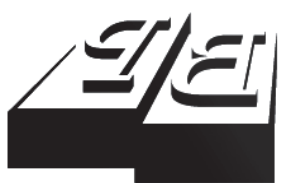

BUSINESS PERSPECTIVES

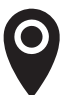

LLC "CPC "Business Perspectives" Hryhorii Skovoroda lane, 10, Sumy, 40022, Ukraine

www.businessperspectives.org

Received on: $27^{\text {th }}$ of March, 2019 Accepted on: $20^{\text {th }}$ of June, 2019

(C) Emre Esat Topaloğlu, Turhan Korkmaz, 2019

Emre Esat Topaloglu, Ph.D., Assistant Professor, Faculty of Economics and Administrative Sciences, Business Administration Department, Şırnak University, Turkey.

Turhan Korkmaz, Ph.D., Professor, Faculty of Economics and

Administrative Sciences, Business Administration Department, Mersin University, Turkey.

\section{() (i)}

This is an Open Access article, distributed under the terms of the Creative Commons Attribution 4.0 International license, which permits unrestricted re-use, distribution, and reproduction in any medium, provided the original work is properly cited.

\title{
THE RELATIONSHIP BETWEEN DERIVATIVE INSTRUMENTS AND SYSTEMATIC RISK: A STUDY ON BANKS TRADING ON BIST
}

\begin{abstract}
This study is aimed to analyze the relationship between the use of derivative financial instruments for speculative and hedging purposes and systematic risk. The effect of the use of derivatives by seven banks trading on Borsa Istanbul during the period of June 2007 - December 2017 on systematic risk was studied using panel cointegration, causality and regression analyses. Banking sector was examined within the scope of the study, since the level of use of derivatives is high in this sector. It was identified in the study that there is a long-run cointegration relationship between the use of derivatives and systematic risk. It was also identified that there is a significant and negative relationship between the use of derivatives for speculative purposes and systematic risk. Furthermore, it was determined that there is a one-way causality relationship from the use of derivatives for speculative purposes towards systematic risk. However, there was no relationship identified between the use of derivatives for hedging purposes and systematic risk. On the other hand, significant and negative relationship was identified between swap transactions that banks use for speculative purposes and systematic risk, while there was no significant relationship determined between forward and option contracts and systematic risk.
\end{abstract}

Keywords derivatives, risk management, banks, panel data analysis

\section{JEL Classification}

\section{C33, G10, G21, G32}

\section{INTRODUCTION}

The activities of firms have reached an international level exceeding national boundaries owing to financial globalization. As a result of the activities firms carry out in financial markets, they encounter some risks. These risks can arise from within the firm as well as from external factors. Risk is described as the possibility of an unanticipated circumstance, while financial risk is the possibility of deviation between realized return and the expected return. The deviation in question can be negative or positive. Total risk is the sum of systematic and unsystematic risks. Unsystematic risks can be mitigated through diversification. Systematic risk is the variability of return on shares or portfolios associated with changes in return on the overall market. In other words, these are the risks that are caused by economic, political and other environmental conditions affecting all firms in business. Systematic risk types generally include inflation risk, currency risk, interest rate risk, market risk and political risk. Unsystematic risk is either a firm-specific threat or a risk that only affects a particular industry. This type of risks generally includes business or industry risk, financial risk and administrative risk. Since the total risk of firms include both systematic and unsystematic risks, it is not possible to reduce systematic risk through diversification in the same economy. Systematic risk that cannot be mitigated through diversification 
in the same economy is an important factor for investors. With regard to systematic risk, CAPM was developed with the studies conducted by Sharpe (1964), Lintner (1965), and Mossion (1966). CAPM is a model generally based on a single variable. Market portfolio is considered as an independent variable in this model, and it is intended to explain returns on all risky securities with returns of market portfolio. Beta coefficient indicates the relationship between returns on a security and the market portfolio. Beta coefficient is the measure of systematic risk. If beta coefficient is 1 , it is understood that the return on the security in question changes at the same rate as the return of market portfolio consisting of all securities. Beta coefficient is the coefficient demonstrating the relationship between changes in share's returns depending on the changes taking place in return rates of market portfolio. The factors affecting a firm's beta coefficient include the capital structure and level and field of activity of that firm.

Firms, especially banks as the financiers of the real economy, operate in futures market for hedging purposes in order to protect their capital within the scope of financial risk management. In this way, banks can make risk transfer by carrying out transactions in futures market by use of derivatives and minimize potential risks that they might come across in the future. Banks can use derivatives consisting of forward, futures, option and swap contracts for primarily hedging, arbitrage and speculative purposes. In this context, it is aimed to reveal the relationship between the use of derivatives by banks and systematic risk in the study. To this end, the data of seven banks trading on Istanbul Stock Exchange during the period of June 2007 - December 2017 were analyzed within the framework of the study.

Risk management is important for banks to be sustainable. Banks can minimize risks and make profit by using derivative instruments. Considering that banks cause systemic risk, it is also important for the economy of the country to perform risk management by using derivative instruments. In this context, researches on the relationship between derivatives and risks keep up to date (Haynes et al., 2019; Vuillemey, 2019). This study has a crucial importance in terms of investigating the short- and long-term relationship between the use of derivatives by banks for hedging and speculative purposes and systematic risk as well as the relationship between speculative forward, swap and option contracts and systematic risk.

\section{LITERATURE REVIEW}

Derivative financial instruments can be used in futures markets in order to measure and avoid market risk, i.e. systematic risk occurring in spot markets that cannot be eliminated through diversification and that investors are obliged to endure, or in order to take a speculative position. There are some studies with respect to this subject both in national and international literature. Descriptions on the findings obtained in these studies are given based on chronological order.

Selvi and Türel (2010), in their study, examined deposit banks in Turkey and the use of derivatives by non-financial corporations as part of financial risk management and the accounting for these usages. According to the results of this examination, it was demonstrated that firms used derivatives for hedging purposes, but they reported the costs and profits resulting from these procedures as held for trading. Alaghi (2011) investigated the association between financial leverage and beta, accepted as the measure of systematic risk, in firms listed on Tehran Stock Exchange. As a result of the study, a significant and negative relationship between financial leverage and systematic risk was identified. In the study conducted by Bartram et al. (2011), the relationship between the use of derivatives by non-financial corporations from 47 countries and firm-specific risk and values was investigated. As a result of the study, it was determined that there was a negative relationship between the use of derivatives and total risk and systematic risk, while there was a positive relationship between firm value and systematic risk. In the study carried out by Coutinho et al. (2012), the effect of the use of derivatives as a risk management instrument by 47 non-financial corporations that were active in Brasil during the period of 2004-2010 on capital risk and cost was analyzed. The results of the analysis demonstrat- 
ed that the use of derivatives affected capital cost in a negative way contrary to what was expected. Hon (2012) studied the use of derivatives by Hong Kong listed firms for financial risk management purposes. As a result of the study, it was identified that using derivatives was useful in avoiding interest rate risks. Keffala and Peretti (2013) investigated the relationship between the use of derivatives by banks in developed countries and borrowing risk along with credit risk and currency risk. The results of the study proved that there is a negative relationship between forward contracts and borrowing risk, while there is a negative relationship between swap contracts and credit risk, and a positive relationship between option contracts and currency risk. Li and Marinc (2014) studied the relationship between the use of derivatives by public banks operating in the USA during the period of 1997-2012 and systematic risk. The findings of the study showed that the use of derivatives by banks increased systematic risk.

Kornel (2014) investigated the relationship between the use of derivatives by public banks operating in Hungary during the period of 2003-2012 and riskiness of banks. As a result of the study, it was determined that there is a negative relationship between the use of derivatives and banking risks. In their study, Şirvan and Alp (2017) aimed to reveal the relationship between the use of derivatives by banks operating in Turkey during the period 2007-2015 and credit risk, and also between market risk and capital adequacy ratio. The results of the study did not suggest any relationship between the use of derivatives and risks. Živanović and Mina (2017) studied the use of derivatives within the context of corporate risk management of non-financial corporations that were active in Serbia. The results of the study revealed that derivatives were ascertained to be useful in avoiding interest and rate risks.

In the light of previous studies on the subject, the relationship between the use of derivatives and systematic risk was addressed in different manners in terms of scope and methodology in this study, and overall, it was examined in a more detailed way. In this context, the information regarding the research on the relationship between the use of derivatives and systematic risk is explained further on.

\section{DATA SET, MODEL AND METHOD}

The objective of the study is to investigate the relationship between the use of derivative financial instruments for speculative and hedging purposes and systematic risk. For that purpose, the data of seven banks trading on Istanbul Stock Exchange during a six-month period of June 2007 - December 2017 were analyzed within the scope of the study. Secondary data concerning the use of derivatives were obtained from balance sheets in the activity reports of banks, while the data regarding systematic risk were obtained from the database www.investing.com. Data on derivatives were available in the activity reports of banks. Systematic risk, on the other hand, was calculated by use of the data obtained from the market. As of 2018, there are 13 banks listed on BIST Bank Index, which was created on December 27, 1996. Seven banks, which were progressively listed on the index during the research period and whose full data could be obtained, were included in the analysis. These banks were Akbank, Denizbank, QNB Finansbank, Türkiye Garanti Bankası, Türkiye İş Bankası, Türkiye Sınai Kalkınma Bankası and Yapıve Kredi Bankası.

As of 2017, there are 52 banks operating in the sector. 34 of them are deposit banks, while 13 of them are development and investment banks, and five of them are participation banks. Three of deposit banks are public-capital banks, while nine of them are private equity banks. There are 13 banks listed on BIST in Turkey. As of December 31, 2017, the amount of total assets in the banking sector has been USD 816.632 million, while the amount of total assets of seven banks examined in the study is USD 416.158 million (https://www.tbb. org.tr). The banks on BIST Bank Index subject to the study represent $51 \%$ of the banking sector in terms of active growth.

Banks use forward, futures, swap and option contracts for speculative and hedging purposes. The data regarding the use of derivatives by banks are specified in financial statements as footnotes. Accordingly, in the activity reports of the banks constituting the sample group of the study, it has been observed that derivatives were used mostly for speculative purposes. On the other hand, 
it was observed during the analysis period that banks used forward, swap and option contracts for speculative purposes, and some banks did not prefer using futures contracts. Thus, futures contracts were not included in the analyses in order to be able to reach more accurate and reliable results in the research.

In the study, both the total uses of derivatives for speculative and hedging purposes were included in the analysis as independent variables as well as the uses of forward, swap and option, while Beta, the measure of systematic risk, was added to the analysis as a dependent variable. Systematic risk is one of the key factors that should be taken into consideration by investors. Capital Asset Pricing Model (CAPM) was suggested by Sharpe (1964) in regard to systematic risk, and it was developed by Linter (1965) and Mossin (1966). The model is based on the inclusion of the systematic risk premium to the riskfree interest rate for determining the expected return of the share. CAPM explains the relationship between systematic risk and share with linear regression model, and Beta coefficient is accepted as the measure of systematic risk that cannot be eliminated through diversification. Beta indicates the sensitivity of a share's return to the return on the market portfolio. Market return, CAPM and Beta are calculated by use of the following formulas.

$$
\begin{aligned}
& R_{t}=\ln \frac{P_{t}}{P_{t-1}}, \\
& R_{i}=R_{f}+\beta_{i}\left(R_{m}+R_{f}\right), \\
& \beta=\frac{\operatorname{Cov}_{i, m}}{\sigma_{m}^{2}},
\end{aligned}
$$

where $R_{i}$ - expected return on a security, $R_{f}=$ Risk-ree rate, $\beta$ - beta of the security, $\operatorname{Cov}_{i, m}$ - covariance between market return and stock return, $\sigma_{m}^{2}$ - variance of the market.

The information regarding the variables used in the study within the scope of the relationship between the use of derivatives for speculative and hedging purposes and systematic risk is indicated in Table 1.

\begin{tabular}{|c|c|c|}
\hline Notation & Variable & Specification \\
\hline BETA & $\begin{array}{l}\text { Beta } \\
\text { coefficient }\end{array}$ & $\begin{array}{l}\text { Covariance between market return } \\
\text { and security return/market return } \\
\text { variance }\end{array}$ \\
\hline SPEC & Speculation & $\begin{array}{l}\text { Derivative financial assets for } \\
\text { marketable securities/total assets }\end{array}$ \\
\hline HED & Hedging & $\begin{array}{l}\text { Derivative financial assets held for } \\
\text { cash flow hedges/total assets }\end{array}$ \\
\hline FRW & Forward & Forward transactions/total assets \\
\hline SWP & Swap & Swap transactions/total assets \\
\hline OPT & Option & Option transactions/total assets \\
\hline
\end{tabular}

Table 1. Variables used in the model

Source: Keffala and Peretti (2013), Kornel (2014).

Panel cointegration, panel causality and panel regression analyses are carried out in order to determine the long-term and short-term relationship between derivatives and systematic risk. Four different models were created within the scope of panel data analyses. In the study, first of all, the long-term relationship between the use of derivatives for speculative and hedging purposes and systematic risk is tested with Kao (1999) and Westerlund (2005) CUSUM Panel Cointegration tests. The models created in regard to cointegration relationship was built as indicated below.

$$
\begin{aligned}
& \Delta \text { beta }_{i t}=\delta_{i}^{\prime} d_{t}+\alpha_{i} y_{i t-1}+\lambda_{i}^{\prime} x_{i t-1}+ \\
& +\sum_{j=1}^{\text {market }} \alpha_{1 i j} \Delta y_{i t-j}^{\text {spec }}+\sum_{j=1}^{\text {market }} \alpha_{2 i j} \Delta y_{i t-j}^{\text {hed }}+e_{i t}, \\
& \text { Beta }_{i t}=\alpha_{i t}+\beta_{1} \text { Spec }_{i t}+\beta_{2} O p t_{i t} .
\end{aligned}
$$

Following the determination of presence of the long-term relationship, Panel DOLS was used to obtain estimates of cointegration coefficient. The model created for Panel DOLS test is as follows:

$$
\operatorname{Beta}_{i t}=\alpha_{i t}+\beta \operatorname{spec}_{1 i t}+\beta \text { hed }_{2 i t}+u_{i t} .
$$

After the coefficients concerning the relationship between variables were estimated, Granger causality test based on Panel VECM was used to reveal if this relationship was a one-way or two-way relationship. The models built in accordance with speculation, hedging and beta variables are as follows:

$$
\begin{aligned}
& \Delta \text { Beta }_{2 i t}=b_{1 i}+\sum_{p=1}^{k} b_{11 i p} \Delta \text { Beta }_{2 i t-p}+ \\
& +\sum_{p=1}^{k} b_{12 i p} \Delta s p e c_{i t-p}+\sum_{p=1}^{k} b_{13 i p} \Delta h e d_{i t-p}+ \\
& +\theta_{1 i} \text { ECM }_{i t-1}+u_{i t},
\end{aligned}
$$




$$
\begin{aligned}
& \Delta \operatorname{spec}_{i t}=b_{2 i}+\sum_{p=1}^{k} b_{21 i p} \Delta \text { Beta }_{2 i t-p}+ \\
& +\sum_{p=1}^{k} b_{22 i p} \Delta \operatorname{spec}_{i t-p}+\sum_{p=1}^{k} b_{23 i p} \Delta h e d_{i t-p}+ \\
& +\theta_{2 i} E C M_{i t-1}+u_{2 i t}, \\
& \Delta h e d_{i t}=b_{3 i}+\sum_{p=1}^{k} b_{31 i p} \Delta B e t a_{2 i t-p}+ \\
& +\sum_{p=1}^{k} b_{32 i p} \Delta \operatorname{spec}_{i t-p}+\sum_{p=1}^{k} b_{33 i p} \Delta h e d_{i t-p}+ \\
& +\theta_{3 i} E C M_{i t-1}+u_{3 i t} .
\end{aligned}
$$

As a result of coefficient estimates and causality analyses regarding the cointegration relationship between the use of derivatives and systematic risk, findings implying the presence of statistically significant relationships between the use of derivatives for speculative purposes and systematic risk were obtained. The potential effects of forward, swap and options as derivatives used by banks for speculative purposes on systematic risk were investigated with Panel regression method. The model created within the framework of panel regression analysis is demonstrated in equation 9 .

$$
\begin{aligned}
& \operatorname{Beta}_{i t}=\beta_{0 i t}+\beta_{1} F r w 1_{i t}+ \\
& +\beta_{2} S w p 2_{i t}+\beta_{3} \operatorname{Opt}_{i t}+\varepsilon_{i t} .
\end{aligned}
$$

Various assumptions should be tested in order to be able to reveal the relationship between variables within the scope of panel data analysis. Accordingly, the assumptions of multicollinearity, cross-sectional dependence, homogeneity and stationarity are tested in panel cointegration, causality and panel regression analyses, while the selection of estimation model and assumptions of autocorrelation and heteroscedasticity are also tested in panel regression analysis.

Whether there is a long-term relationship between the use of derivatives for speculative and hedging purposes and systematic risk is analyzed with Kao (1999) and Westerlund (2005) CUSUM panel cointegration tests. Kao panel cointegration test is based on DF and ADF tests (Baltagi et al., 2000, p. 13; Asteriou \& Hall, 2007, p. 372). This test includes null hypothesis assumptions where there is no cross-sectional hypothesis trend and cointegration. In the study, Kao test was employed using Newey-West estimators in order to reach Schwarz criterion and long-term variance when an individual constant exists. CUSUM test is used to make an assumption on cross-sectional dependence and hypothesis testing are reversed. Thus, it is implied that there is cointegration under the null hypothesis in a CUSUM test. After the determinating a cointegration relationship, Pedroni's Dynamic Ordinary Least Squares (DOLS) method was used to detect the direction and the level of existing long-term relationship. In line with the long-term cointegration relationship, under the assumption that series are static, both long and short-term causality relationships between variables were analyzed. Granger causality test was based on the Panel Vector Error Correction Model (VECM).

\section{RESEARCH RESULTS}

In the study, the use of derivatives by banks was addressed generally in terms of speculative and hedging purposes, while derivatives used for speculative purposes were also addressed individually. In this context, long-term cointegration relationship between the total fund amounts attributed to derivatives was used for speculative and hedging purposes, and beta, the measure of systematic risk was tested, and it was investigated if the potential effect had a one-way and/or two-way causality relationship by making coefficient estimations. Later on, the relationship between forward, swap and option contracts used for speculative purposes and systematic risk was examined. When the activity reports of banks during the analysis period were reviewed, it was observed that banks did not prefer using futures contracts for speculative purposes. It was seen that Akbank, Denizbank, Türkiye İş Bankasi, Türkiye Sınai Kalkinma Bankasi and Yapive Kredi Bankasi did not use futures during certain stages of the research period. Thus, futures contracts were not included in the analyses in order to be able to reach more accurate and reliable results in the research. For this reason, the study is composed of two parts where the long-term relationship between the use of derivatives for speculative and hedging purposes and systematic risk and the short-term relationship between the use of derivatives for speculative purposes and system- 
Table 2. The results of multicollinearity analysis

\begin{tabular}{|c|c|c|c|c|c|c|}
\hline $\begin{array}{c}\text { Variance } \\
\text { coefficient }\end{array}$ & Uncentered VIF & Centered VIF & Correlation & BETA & SPEC & HED \\
\hline- & - & - & BETA & 1.000 & - & - \\
\hline 8.445 & 1.586 & 1.310 & SPEC & -0.141 & 1.000 & - \\
\hline 2.961 & 1.356 & 1.310 & HED & 0.071 & 0.205 & 1.000 \\
\hline 0.004 & 1.212 & NA & C & - & - & - \\
\hline
\end{tabular}

Table 3. The results of test examining multicollinearity among derivatives

\begin{tabular}{|c|c|c|c|c|c|c|c|}
\hline $\begin{array}{c}\text { Variance } \\
\text { coefficient }\end{array}$ & Uncentered VIF & Centered VIF & Correlation & BETA & FRW & OPT & SWAP \\
\hline- & - & - & Beta & 1.000 & - & - & - \\
\hline 139.687 & 1.073 & 1.055 & Forward & -0.035 & 1.000 & - & - \\
\hline 73.587 & 1.254 & 1.238 & Option & -0.128 & 0.258 & 1.000 & - \\
\hline 7.912 & 1.442 & 1.256 & Swap & -0.107 & 0.333 & 0.237 & 1.000 \\
\hline 0.005 & 1.236 & NA & C & - & - & - & - \\
\hline
\end{tabular}

atic risk are analyzed separately. Accordingly, the analyses made and the findings obtained are specified below. The first assumption that should to be tested within the framework of panel data analyses is multicollinearity. The results of Spearman correlation analysis conducted for multicollinearity and variance inflation factor test are indicated in Tables 2 and 3.

The correlation coefficient between variables higher than 0.90 and VIF values greater than 10 indicate the presence of the problem of multicollinearity (Tabachnick \& Fidell, 2001; Hair et al., 1998). According to the results of correlation and VIF analysis conducted to test the assumption of multicollinearity, it was identified that the level of relationship among the BETA, SPEC and HED variables was 0.20 , while VIF values were 1.310 . Hence, there is no question of multicollinearity between the explanatory variables and in the panel. The results of correlation analysis suggested that the highest level of relationship between BETA, FRW,
$O P T$ and SWAP variables was 0.333 , and VIF value was smaller than 10 , which is accepted as critical value. According to the correlation and VIF test results, no findings were found indicating the problem of multicollinearity between explanatory variables. Explanatory statistical data regarding the dependent and independent variables are indicated in Table 4.

When the average values regarding explanatory and independent variables are analyzed, it is seen that the average value of the use of derivatives for speculation among total assets was 0.011, while the average value of the use of derivatives for hedging was 0.007 . Therefore, it is possible to state that banks trading on BIST Bank Index use derivatives for speculative purposes more than for hedging purposes. Moreover, it can be said that banks used swap contracts the most, followed by options and forward contracts. The average value for beta, which indicates the sensitivity of a share's return to the return on the market portfolio and

Table 4. Descriptive statistics

\begin{tabular}{|c|c|c|c|c|c|c|}
\hline & BETA & SPEC & HED & FORWARD & OPTION & SWAP \\
\hline Mean & 0.990171 & 0.011528 & 0.007961 & 0.000722 & 0.000939 & 0.009818 \\
\hline Median & 1.065843 & 0.005874 & $8.72 E-07$ & 0.000423 & 0.000566 & 0.004434 \\
\hline Maximum & 4.923800 & 0.133907 & 0.466540 & 0.053902 & 0.039253 & 0.197251 \\
\hline Minimum & -3.088771 & -0.058047 & -0.077743 & -0.022851 & -0.070518 & -0.070892 \\
\hline Std. dev. & 0.788595 & 0.025212 & 0.042579 & 0.005579 & 0.008325 & 0.025569 \\
\hline Skewness & -0.591150 & 1.673998 & 8.535916 & 4.897849 & -3.457087 & 3.070718 \\
\hline Kurtosis & 11.41738 & 8.805700 & 89.84102 & 57.71302 & 40.14997 & 23.00958 \\
\hline Jarque-Bera & 463.6046 & 288.2061 & 50260.54 & 19824.10 & 9162.525 & 2811.145 \\
\hline J-B prob. & 0.000000 & 0.000000 & 0.000000 & 0.000000 & 0.000000 & 0.000000 \\
\hline Observations & 154 & 154 & 154 & 154 & 154 & 154 \\
\hline
\end{tabular}


Table 5. The results of cross-sectional dependence test on the basis of panel and variable

\begin{tabular}{|c|c|c|c|c|}
\hline \multirow[t]{2}{*}{ Variable } & \multicolumn{2}{|c|}{$\begin{array}{c}\text { LM } \\
\text { (Breusch \& Pagan, 1980) }\end{array}$} & \multicolumn{2}{|c|}{$\begin{array}{c}\text { CDLM } \\
\text { (Pesaran, 2004) }\end{array}$} \\
\hline & Statistics & Prob. & Statistics & Prob. \\
\hline PANEL A & 21.433 & 0.433 & 0.067 & 0.473 \\
\hline BETA & 30.161 & 0.089 & 1.414 & 0.079 \\
\hline SPEC & 58.258 & 0.000 & 5.749 & 0.000 \\
\hline HED & 56.174 & 0.000 & 5.427 & 0.000 \\
\hline PANEL B & 32.990 & 0.046 & 1.850 & 0.032 \\
\hline BETA & 30.610 & 0.080 & 1.483 & 0.069 \\
\hline FORWARD & 68.091 & 0.000 & 7.266 & 0.000 \\
\hline OPTION & 56.622 & 0.000 & 5.497 & 0.000 \\
\hline SWAP & 57.428 & 0.000 & 5.621 & 0.000 \\
\hline
\end{tabular}

which is the measure of systematic risk, is calculated as 0.99 in banks according to the results of descriptive statistics analysis. If there is cross-sectional dependence between series, analyses should be made taking this fact into consideration for the sake of accuracy and reliability of the findings to be obtained (Breusch \& Pagan, 1980; Pesaran, 2004). Results of analyses where cross-sectional dependence is not taken into consideration can include deviation and become incoherent. Cross-sectional dependence between series was analyzed by use of Breusch-Pagan (1980) LM test and Pesaran (2004) CDLM tests due to the fact that time dimension of the study is greater than its cross-section dimension $(T>N)$. The results of the CSD test are indicated in Table 5.

According to the CSD test results of Panel A, it was determined that probability values of beta as the dependent variable based on probability values of CSD test carried out on variable basis were above the critical value and that they did not include cross-sectional dependence. On the other hand, probability values for SPEC and HED variables were found to be below the critical value, and the null hypothesis was rejected. In this re- gard, it is not possible to mention cross-sectional independence in terms of these two variables. The cross-sectional dependence test results of Panel B suggested that probability values for forward, option and swap variables were below the critical value, and the null hypothesis indicating nonexistence of cross-sectional dependence was rejected. Accordingly, it was revealed that there is no cross-sectional independence in the series.

Whether the stationarity assumption is investigated by use of first or second generation, unit root test within panel data analysis is decided by use of the assumption of homogeneity. The results of analysis made in accordance with homogeneity and heterogeneity of variables are indicated in Table 6 .

The examination of the results of homogeneity test for Panel A and B suggested that probability values for all the variables were above the critical value, and the null hypothesis was not rejected. Accordingly, it was determined that slope coefficients of all three variables were homogeneous. In compliance with the presence of cross-sectional dependence and homogeneous structure identified in series, stationarity testing was carried out

Table 6. The results of the Pesaran and Yamagata (2008) homogeneity test

\begin{tabular}{|c|c|c|c|c|c|}
\hline & Variable & $\tilde{\Delta}$ & Prob. & $\tilde{\Delta}_{\text {adj }}$ & Prob. \\
\hline \multirow{3}{*}{ PANEL A } & BETA & 0.498 & 0.309 & 0.536 & 0.296 \\
\hline & SPEC & -1.760 & 0.961 & -1.893 & 0.971 \\
\hline & HED & -1.042 & 0.851 & -1.121 & 0.869 \\
\hline \multirow{4}{*}{ PANEL B } & BETA & 0.498 & 0.309 & 0.536 & 0.296 \\
\hline & FORWARD & -1.377 & 0.916 & -1.482 & 0.931 \\
\hline & OPTION & -1.726 & 0.958 & -1.857 & 0.968 \\
\hline & SWAP & -1.545 & 0.939 & -1.662 & 0.952 \\
\hline
\end{tabular}


by use of Bai and Ng (2004) PANIC unit root test, one of the second generation tests taking cross-sectional dependence and homogeneity into account. For BETA variable, which is homogeneous and includes CSD with a significance level of 0.10, PANIC second generation and Levin, Lin, and Chu (2002) (LLC) first generation unit root tests were used to investigate the stationarity assumption. The results of unit root test are indicated in Table 7.

The examination of the results of PANIC test used in the presence of cross-sectional dependence and homogeneity suggested that probability values for BETA, SPEC, HED, FORWARD, $O P T I O N$ and SWAP variables were below the critical value, and the null hypothesis was rejected. Therefore, it was determined that all variables were stationary at level. The examination of the results of LLC test suggested that proba- bility values for $B E T A$ variable were below the critical value, and the null hypothesis indicating nonexistence of stationarity was rejected. In this context, it was determined that series associated with BETA variable were stationary at level. This finding shows parallelism with the findings obtained from PANIC test.

It was revealed that series related to all variables were stationary at the same level according to the stationarity testing conducted on explanatory and dependent variables. The long-term relationship, namely cointegration relationship between variables having the same level of stationarity, can be analyzed. The long-term relationship between the use of derivatives and systematic risk was examined using Panel CUSUM and Kao Panel Cointegration tests. Test results are indicated in Table 8.

Table 7. The results of PANIC and LLC panel unit root tests

\begin{tabular}{|c|c|c|c|c|}
\hline \multirow{2}{*}{ Level } & \multicolumn{2}{|c|}{ Intercept } & \multicolumn{2}{|c|}{ Intercept and trend } \\
\hline & Statistics & Prob. & Statistics & Prob. \\
\hline \multicolumn{5}{|c|}{ PANIC panel unit root tests } \\
\hline \multicolumn{5}{|c|}{ BETA } \\
\hline$Z_{\widehat{e}}^{c}$ & $7.0153^{* * *}$ & 0.0000 & $6.1166^{* * *}$ & 0.0000 \\
\hline$P_{\widehat{e}}^{c}$ & $51.1213^{* * *}$ & 0.0000 & $46.3659 * * *$ & 0.0000 \\
\hline \multicolumn{5}{|c|}{ SPEC } \\
\hline$Z_{\hat{e}}^{c}$ & $3.9444 * * *$ & 0.0000 & $3.2200 * * *$ & 0.0006 \\
\hline$P_{\widehat{e}}^{c}$ & $34.8717^{* * *}$ & 0.0015 & $31.0389 * * *$ & 0.0055 \\
\hline \multicolumn{5}{|c|}{ HED } \\
\hline$Z_{\hat{e}}^{c}$ & $2.4760 * * *$ & 0.0066 & $3.0392 * * *$ & 0.0012 \\
\hline$P_{\widehat{e}}^{c}$ & $27.1018^{* *}$ & 0.0187 & $30.081^{* * *}$ & 0.0074 \\
\hline \multicolumn{5}{|c|}{ FORWARD } \\
\hline$Z_{\widehat{e}}^{c}$ & 6.2384 & $0.0000 * * *$ & 4.0618 & $0.0000^{* * *}$ \\
\hline$P_{\widehat{e}}^{c}$ & 47.0103 & $0.0000 * * *$ & 35.4929 & $0.0012^{* * *}$ \\
\hline \multicolumn{5}{|c|}{ OPTION } \\
\hline$Z_{\widehat{e}}^{c}$ & 3.8739 & $0.0001^{* * *}$ & 2.4050 & $0.0081^{* * *}$ \\
\hline$P_{\widehat{e}}^{c}$ & 34.4985 & $0.0017^{* * *}$ & 26.7258 & $0.0209 * *$ \\
\hline \multicolumn{5}{|c|}{ SWAP } \\
\hline$Z_{\hat{e}}^{c}$ & 3.1814 & $0.0007 * * *$ & 2.9702 & $0.0015^{* * *}$ \\
\hline$P_{\widehat{e}}^{c}$ & 30.8343 & $0.0058 * * *$ & 29.7169 & $0.0083^{* * *}$ \\
\hline \multicolumn{5}{|c|}{ LLC panel unit root test } \\
\hline BETA & -9.207 & $0.0000 * * *$ & -8.024 & $0.0000^{* * *}$ \\
\hline
\end{tabular}

Note: $* * *, * *$ and $*$ denote the significance at the 1,5 and 10 per cent levels, $H_{0}$ : Unit Root. 
Table 8. The results of Kao and CUSUM cointegration tests

\begin{tabular}{l|c:c}
\hline & t-statistics & Prob. \\
\hline \multicolumn{3}{c}{ Kao cointegration tests } \\
\hline ADF & $-2.564^{* * *}$ & 0.0052 \\
Residual variance & 0.909 & ????? \\
\hline HAC variance & 0.126 & \\
\hline \multicolumn{2}{c}{ DOLS-based CUSUM test } \\
\hline $\begin{array}{l}\text { CUSUM cointegration } \\
\text { tests }\end{array}$ & 1.583 & $0.057^{*}$ \\
\hline
\end{tabular}

Note: $* * *, * *$ and $*$ denote the significance at the 1,5 and 10 per cent levels, $H_{0}$ : Cointegration.

According to the results of Panel CUSUM cointegration test, the null hypothesis indicating the presence of cointegration among series cannot be rejected. In other words, it was identified that series act together in the long term, and the problem of spurious regression cannot be encountered in model estimations to be conducted with the level values of these series. The presence of a long-term cointegration relationship between series was also investigated with Kao cointegration test, which has a null hypothesis according to CUSUM test. According to the results of Kao cointegration test, the null hypothesis indicating the nonexistence of cointegration among series was rejected. In this regard, it was put forward that there was a long-term cointegration relationship between series. The results obtained from Kao test support the Panel CUSUM test results.

After unveiling a long-term cointegration relationship between the use of derivatives for speculative and hedging purposes and systematic risk, Panel DOLS estimation method was used to detect the direction and coefficient of the relationship between variables. The results of Panel DOLS test are indicated in Table 9.

Table 9. The results of the Panel DOLS test

\begin{tabular}{l|c}
\hline \multicolumn{1}{c}{ Variable } & PANEL BETA \\
\hline Period & June 2007-December 2017 \\
\hline Method & Panel DOLS \\
\hline Speculation & $-20.775(0.027)^{* *}$ \\
\hline Hedging & $2.0472(0.657)$ \\
\hline$R^{2}$ & 0.430 \\
\hline Regression S.E. & 0.774 \\
\hline Long-run variance & 0.373 \\
\hline Mean dep. var. & 0.997 \\
\hline S.D. dep. var. & 0.808 \\
\hline Akaike information criterion & 49.195 \\
Observations & 154 \\
\hline
\end{tabular}

Note: $* * *, * *$ and $*$ denote the significance at the 1,5 and 10 per cent levels.
The results of Panel DOLS tests suggested that there was a statistically significant and negative relationship between the use of derivatives for speculative purposes and systematic risk. An alteration of one-unit in derivatives used by banks for speculative purposes leads to a decrease of 20.775 units in systematic risk. However, there was no relationship identified between the use of derivatives for hedging purposes and systematic risk. Granger causality analysis based on Panel VECM was used to determine and analyze further if the relationship between the use of derivatives and systematic risk is a one-way and/or two-way relationship. Test results are indicated in Table 10.

Table 10. The results of the Granger causality test based on panel VECM

\begin{tabular}{|c|c|c|c|c|}
\hline & \multicolumn{3}{|c|}{ Short-term causality } & \multirow{2}{*}{$\begin{array}{c}\begin{array}{c}\text { Long-term } \\
\text { causality }\end{array} \\
\text { ECT (-1) }\end{array}$} \\
\hline & $\Delta($ BETA $)$ & $\Delta$ (SPEC) & $\Delta$ (HED) & \\
\hline$\Delta(\mathrm{BETA})$ & - & $\begin{array}{c}1.752 \\
{[0.6252]}\end{array}$ & $\begin{array}{c}0.823 \\
{[0.8438]}\end{array}$ & $12.005(0.0619)^{*}$ \\
\hline$\Delta(\mathrm{SPEC})$ & $\begin{array}{c}11.664 \\
{[0.0086]^{* * *}}\end{array}$ & - & $\begin{array}{c}0.904 \\
{[0.8243]}\end{array}$ & $1.859(0.9322)$ \\
\hline$\Delta(\mathrm{HED})$ & $\begin{array}{c}2.776 \\
{[0.4274]}\end{array}$ & $\begin{array}{c}0.139 \\
{[0.9867]}\end{array}$ & - & $1.656(0.9485)$ \\
\hline
\end{tabular}

Note: ${ }^{* * *}$ and $*$ denote the significance at the 1 and 10 per cent levels. Maximum lag number is set to 2 and optimal lags for each country is determined by the means of the Akaike information criterion.

The results of the Granger causality analysis based on Panel VECM proved a one-way causality relationship between the use of derivatives for speculative purposes and systematic risk, while no causality relationship between the use of derivatives for hedging purposes and systematic risk was unveiled.

As a result of coefficient estimates and causality analyses regarding the cointegration relationship between the use of derivatives and systematic risk, findings implying the presence of statistically significant relationships between the use of derivatives for speculative purposes and systematic risk were obtained. The potential effects of forward, swap and option contracts used by banks for speculative purposes on systematic risk were explored with Panel EKK method and lengthier findings were obtained. 
Table 11. The results of panel data analysis

\begin{tabular}{|c|c|}
\hline Variable & PANEL BETA \\
\hline Period & June 2007 - December 2017 \\
\hline Method & White Cross-Section \\
\hline FORWARD & $-7.205(0.666)$ \\
\hline OPTION & $-8.126(0.305)$ \\
\hline SWAP & $-6.771(0.009)^{* * *}$ \\
\hline C & $30.705(0.000)^{* * *}$ \\
\hline F-gs & $9.487(0.000)$ \\
\hline F-zs & $0.971(0.503)$ \\
\hline F-gzs & $2.812(0.000)$ \\
\hline LM-gr & $96.318(0.000)$ \\
\hline LM-zr & $1.763(0.184)$ \\
\hline LM-gzr & $98.082(0.000)$ \\
\hline Honda-gr & $9.814(0.000)$ \\
\hline Honda-zr & $-1.328(0.907)$ \\
\hline Honda-gzr & $6.000(9.83 E-1)$ \\
\hline Hausman & $0.627(0.890)$ \\
\hline BPG-LM & $82.357(0.000)$ \\
\hline BL-LM & $0.092(0.760)$ \\
\hline BB-LM & $0.783(0.376)$ \\
\hline$D W\left(d_{p 1} 1.9117-d_{P U} 1.9206\right)$ & 1.975 \\
\hline$R^{2}$ & 0.385 \\
\hline F-statistics & 2.577 \\
\hline Prob. & $0.000 * * *$ \\
\hline Regression S.E. & 0.689 \\
\hline Mean. dep. var. & 0.990 \\
\hline S.D. dep. var. & 0.788 \\
\hline Akaike info criterion & 2.271 \\
\hline Hannan-Quinn info criterion & 2.519 \\
\hline Observations & 154 \\
\hline
\end{tabular}

Note: F-gs - F-group_fixed, F-zs - F-period_fixed, F-gzs F-two way_fixed, LM-gr - LM-group_random, LM-zr - LMperiod_random, LM-gzr - LM-two way_random, BPG LM Breusch-Pagan-Godfrey LMh_fixed, $B L-\bar{L} M$ - Baltagi and Li (1991) LMp, BB-LM, Born and Bretuing (2016) LMp, DW Durbin-Watson, $R^{2}-\mathrm{R}$-squared. ${ }^{* * *}, * *$ and $*$ denote the significance at the 1,5 and 10 per cent levels.

When the results of panel data analysis are examined, it is anticipated that using fixed effects model to estimate the model created based on F, LM and
Honda test results would provide more accurate results. In the case that the data used in a study are created based on a specific group and a certain period, a one-way fixed effects model where group effects are taken into consideration should be used in the final estimation of models (Baltagi, 2005). In this context, it was ascertained that using fixed effects model for model estimation would provide more accurate, reliable and consistent results according to the fact that a sample group was incidentally not formed and that the data of a specific group from a certain period was used. Heteroscedasticity in model error terms was investigated by use of Breusch-Pagan-Godfrey Heteroscedasticity LM. The result of the analysis suggested that there was a heteroscedasticity problem (BPG-LM, 82.3570.000 ) in the model. Autocorrelation, on the other hand, was analyzed by Baltagi and Li (1991), Born and Bretuing (2016) and Bhargava, Franzini, and Narendranathan (1982) in Durbin-Watson tests. The results of the test put forward that there was not autocorrelation between error terms in the model (BL-LM, 0.092-0.760; BB-LM, 0.783-0.376; DW, 1.975). Accordingly, model estimation was performed with White Cross-Section, resistant estimator correcting panel standard errors, which solves the problem of heteroscedasticity identified in the model. The results of the model prove that F-statistic probability value indicating the overall significance of the model was significant at the $99 \%$ confidence interval, and that independent variables explain 0.385 of changes in the dependent variable $\left(R^{2}\right)$. In the model, it was determined that there was a statistically significant and negative relationship between swap contracts used for speculative purposes and systematic risk. An alteration of one-unit in swap contracts leads to a decrease of 6.771 units in systematic risk. However, there was no significant relationship identified between forward and option contracts and systematic risk. Thus, banks should feature swap contracts instead of forward and option contracts in order to be able to minimize systematic risk. The fact that banks prefer swap contracts more in terms of the amount of use of derivatives supports the findings obtained.

\section{CONCLUSION}

This study was aimed to reveal the relationship between the use of derivatives during the period of June 2007 - December 2017 for speculative and hedging purposes and systematic risk. Significant and neg- 
ative relationship was identified in the long run between the use of derivatives by banks for speculative purposes and systematic risk, while there was no relationship determined between the use of derivatives by banks for hedging purposes and systematic risk. This finding obtained in the study shows similarity with the findings obtained by Bartram et al. (2011).

Causality analysis showed that it was determined that there was a one-way causality relationship between the use of derivatives for speculation and systematic risk, which supported previous findings. However, there was no causality relationship identified between the use of derivatives for hedging purposes and systematic risk. The findings obtained share similarities with the findings reached in the studies carried out by Keffala and Peretti (2013).

Banks should prefer using swap contracts rather than forward and option contracts in order to protect their capital, use their resources efficiently and maximize their profit by minimizing the market risk. The study can be improved by including non-public banks to the analysis, making comparisons with the banking sectors of other countries and applying different methodological approaches.

\section{REFERENCES}

1. Alaghi, K. (2011). Financial leverage and systematic risk. African Journal of Business Management, 5(15), 66486650. https://doi.org/10.5897/ AJBM11.335

2. Asteriou, D., \& Hall, S. G. (2007). Applied econometrics: A modern approach using eviews and microfit. New York: Palgrave Macmillan.

3. Bai, J., \& Ng, S. (2004). A panic attack on unit roots and cointegration. Econometrica, 72(4), 1127-1177. Retrieved from https:// www.jstor.org/stable/3598781

4. Baltagi, B. H. (2005). Econometric analysis of panel data (3rd ed.). West Sussex: Wiley.

5. Baltagi, B. H., \& Kao, C. (2000). Nonstationary panels, cointegration in panels: A survey (Working Paper No. 16). Center for Policy Research. Retrieved from https:// surface.syr.edu/cgi/viewcontent. cgi? article $=1135 \&$ context $=\mathrm{cpr}$

6. Baltagi, B. H., \& Li, Q. (1991). A joint test for serial correlation and random individual effects. Statistics and Probability Letters, 11, 277-280.

7. Bartram, S. M., Brown, G. W., \& Conrad, J. (2011). The effects of derivatives on firm risk and value. Journal of Financial and Quantitative Analysis, 46(4), 967-999. https://doi.org/10.1017/ S0022109011000275
8. Bhargava, A., Franzini, L., \& Narendranathan, W. (1982). Serial Correlation and the fixed effects model. The Review of Economic Studies, 49(4), 533-549. https://doi. org/10.2307/2297285

9. Born, B., \& Breitung, J. (2016). Testing for serial correlation in fixed-effects panel data models. Econometric Reviews, 35(7), 12901316. https://doi.org/10.1080/0747 4938.2014.976524

10. Breusch, T., \& Pagan, A. (1980). The Lagrange multiplier test and its applications to model specification in econometrics. Review of Economic Studies, 47(1), 239-253. https://doi. org/10.2307/2297111

11. Coutinho, J. R. R., Sheng, H. H., \& Lora, M. I. (2012). The use of FX derivatives and the cost of capital: Evidence of Brazilian companies. Emerging Markets Review, 13(4), 411-423. https://doi.org/10.1016/j. ememar.2012.07.001

12. Granger, C. W. J. (1969). Investigating causal relations by econometric models and crossspectral methods. Econometrica, 37(3), 424-438. https://doi. org/10.2307/1912791

13. Hair, J., Erson, R. E., Tatham, R., \& William, C. B. (1998). Multivariate Data Analysis. New Jersey: Prentice-Hall.
14. Haynes, R., McPhail, L., \& Zhu, H. (2019). When leverage ratio meets derivatives: Running out of options? (SSRN paper). http://dx.doi. org/10.2139/ssrn.3378619

15. Hon, T. Y. (2012). Managing financial risk by using derivatives: A study of Hong Kong listed companies. ELK Asia Pacific Journal of Finance and Risk Management, 4(1), 1-16.

16. Honda, Y. (1985). Testing the error components model with non-normal disturbances. The Review of Economic Studies, 52(4), 681-690. https://doi. org/10.2307/2297739

17. Kao, C. (1999). Spurious regression and residual based tests for cointegration in panel data. Journal of Econometrics, 90(1), 1-44. https://doi.org/10.1016/ S0304-4076(98)00023-2

18. Keffala, M. R., \& Peretti, C. (2013). Effect of use derivative instruments on accounting risk: Evidence from banks in emerging and recently developed countries. Annals of Economics and Finance, 14(1), 149-178. https://doi. org/10.13140/2.1.1548.9929

19. Kornel, T. (2014). The effect of derivative financial instruments on bank risks, relevance and faithful representation: Evidence from banks in Hungary. Annals 
of Faculty of Economics, 1(1), 698-706. Retrieved from https:// ideas.repec.org/a/ora/journl/ v1y2014ilp698-706.html

20. Levin, A., Lin, C., \& Chu, C. S. J. (2002). Unit root tests in panel data: Asymptotic and finite-sample properties. Journal of Econometrics, 108(1), 1-24. https://doi.org/10.1016/S03044076(01)00098-7

21. Li, S., \& Marinc, M. (2014). The use of financial derivatives and risks of U.S. bank holding companies. International Review of Financial Analysis, 35, 4671. https://doi.org/10.1016/j. irfa.2014.07.007

22. Lintner, J. (1965). The valuation of risk assets and the selection of risky investments in stock portfolios and capital budgets. Review of Economics and Statistics, 47(1), 13-37. https://doi. org/10.2307/1924119

23. Mossin, J. (1966). Equilibrium in a capital asset market. Econometrica,
34(4), 768-783. https://doi. org/10.2307/1910098

24. Pesaran, H. (2004). General diagnostic tests for cross section dependence in panels (IZA Discussion Paper No. 1240). Retrieved from http://ftp.iza.org/dp1240.pdf

25. Pesaran, H., \& Yamagata, $T$. (2008). Testing slope homogeneity in large panels. Journal of Econometrics, 142(1), 50-93. https://doi.org/10.1016/j.jeconom.2007.05.010

26. Selvi, Y., \& Türel, A. (2010). Derivatives usage in risk management by Turkish nonfinancial firms and banks: A comparative study. Annales Universitatis Apulensis: Series Oeconomica, 12(2), 663-671.

27. Sharpe, W. F. (1964). Capital asset prices: A theory of market equilibrium under conditions of risk. The Journal of Finance, 19(3), 425-442. https://doi. org/10.1111/j.1540-6261.1964. tb02865.x
28. Şirvan, N., \& Sezgin Alp, Ö. (2017). Türk bankacılık sektöründe Türev piyasa araçlarının riske etkileri. Ticari Bilimler Fakültesi Dergisi, 1, 130157.

29. Tabachnick, B. G., \& Fidell, L. S. (2001). Using multivariate statistics. Boston: Allyn and Bacon.

30. Vuillemey, G. (2019). Bank interest rate risk management. Management Sciences, 1-56. https:// doi.org/10.1287/mnsc.2018.3125

31. Westerlund, J. (2005). A panel CUSUM test of the null of cointegration. Oxford Bulletin of Economics and Statistics, 67(2), 305-339. https://doi.org/10.1111/ j.1468-0084.2004.00118.x

32. Živanović, B., \& Mina, K. (2017). The usage of financial derivatives in financial risk management by non-financial companies in Serbia. Industrija, 45(3), 65-82. https://doi.org/10.5937/industrija45-14079 